\title{
Rевевки автісі: : Symptomatology and pathogenic variability of Alternaria carthami isolates from Maharashtra state infecting safflower crop
}

\author{
S.S. WAGH, A.P. SURYAWANSHI AND P.G. CHAVAN
}

Article Chronicle:

Received :

19.07.2017;

Accepted :

03.08.2017

KEY WoRds:

Pathogen, Safflower crop, Viruses, Fungal diseases
SUMMARY : The pathogen (Alternaria carthami) was isolated successfully from the naturally diseased safflower leaf specimens collected during survey and one each representative isolate from twenty districts of Maharashtra state were obtained, purified and maintained. The pathogenicity test attempted on susceptible safflower cv. MANJIRA in pot culture under screen house, clearly indicated that all the 20 isolates of A. carthami exhibited a wide range of pathogenic variability. However, the aggressive isolates (viz., AcHl, AcBl, AcAn, AcJg, etc.) showed least incubation period, highest leaf spot frequency with maximum sized leaf spots. Whereas, moderately virulent / aggressive isolates exhibited moderate incubation period, leaf spot frequency and their size. In less virulent isolates viz., AcAm, AcDl, AcNb and AcNs through incubation period was maximum ( $>9$ days), but leaf spot frequency and their size were of lower minimum. Based on symptomatology, cultural and morphological characteristics, microscopic and pathogenicity test, the test pathogen was identified as Alternaria carthami, compared with the descriptions of Alternaria spp. (Simmons, 2007) and finally confirmed as Alternaria carthami, the incitant of leaf spot / blight in safflower.

How to cite this article : Wagh, S.S., Suryawanshi, A.P. and Chavan, P.G. (2017). Symptomatology and pathogenic variability of Alternaria carthami isolates from Maharashtra state infecting safflower crop. Agric. Update, 12(TECHSEAR-7) : 1983-1989; DOI: 10.15740/HAS/AU/12.TECHSEAR(7) 2017/1983-1989.

\section{Author for correspondence :}

\section{S.S. WAGH}

Department of Plant Pathology, College of Agriculture, Vasantrao Naik Marathwada Krishi Vidyapeeth, PARBHANI (M.S.) INDIA

Email : drwaghss@ gmail.com

See end of the article for authors' affiliations 